Our Nature (2009) 7:168-176

\title{
Dynamics of Zooplankton in Relation to Physico-chemical Factors
}

\author{
I.A. Dar ${ }^{1^{*}}$, H.A. Rather ${ }^{2}$ and M.A. Dar ${ }^{1}$ \\ ${ }^{1}$ Department of Industries and Earth Sciences, Tamil University, Thanjavr- TN, India ${ }^{2}$ Department of \\ Biotechnology, Sharmila Institute of Medicinal Plant Biotechnology, Thanjavur-TN, India \\ "E-mail:wonder_env@yahoo.com
}

Received: 11.06.2009, Accepted: 24.11.2009

\begin{abstract}
The present investigation deals with limno- biotic status of the Bhoj wetland from January to August, 2009. From the data it was apparent that correlations between the physico-chemical factors and dynamics of zooplankton could be seen. Systematic sampling was done and five sampling stations were selected. The main objective of this research was to evaluate the correlation of zooplankton diversity with the physico-chemical factors. The analys is of data showed a positive correlation of copepods with temperature, indicating that the copepods develop better in warm periods after a mild and dump winter. While rotifers showed a negative correlation with temperature and a positive correlation with $\mathrm{pH}$ - value.
\end{abstract}

Key words: Zooplankton, Physico-chemical parameters, Rotifera, Correlation

\section{Introduction}

Rotifers, Cladocerans, Copepods and Ostracods constitute the major groups of zooplankton. They occupy an intermediate position in the food web and mediate the transfer of energy from lower to higher trophic levels (Waters, 1987). Being heterotrophic in nature, they play a key role in cycling of organic materials in an aquatic ecosystem (Gupta and Sharma, 2007). Zooplankton communities are typically diverse and occur almost in all lakes and ponds and are highly sensitive to environmental variation. Due to short life cycle, these communities often respond quickly to environmental change (Sharma et al., 2007). The phenomenon of cultural eutrophication, siltation, predation, habitat destruction etc. excise drastic impact on their community structure (Wanganeo, 2007). Some biologists considered role of zooplankton in determining the trophic status of water body.

The studies of both abiotic and biotic components are complementary to each other. The abiotic environments give information about the type of a substance or pollutant and its concentration while biotic components indicate their general effect. Biological components show the degree of ecological imbalance which has been caused. The changes in physico-chemical conditions of water can be reflected directly in the biotic community of ecosystem.

Zooplankton have great significance as pollution indicators. As a major element in aquatic biota, the zooplankton community often exhibits dramatic changes in response to the changes in the physic-chemical properties of the aquatic environment. Hence zooplankton fauna or zooplankton 
association can be used as useful means for the assessment of water pollution. The present paper analyses the eight month time series (January to August, 2009) of the zooplankton community structure. Special attention is paid at analyzing species composition and seasonal pattern, and at evaluating the relationships among different zooplankton groups and abiotic factors.

\section{Materials and methods \\ Study area}

The Bhoj Wetland is located in Bhopal city, the state capital of Madhaya Pradesh, India. The wetland consisting of two lakes (Upper and Lower lakes) are manmade reservoirs. The Upper lake created in the 11th century by constructing an earthen dam across the Kolans river and the lower lake constructed nearly two centuries ago immediately downstream of the Upper lake, have catchment of 361 and $9.6 \mathrm{~km}^{2}$, respectively. Bhoj Wetland has been designated as a Ramsar site in November 2002. The Upper Lake has a partial urban component in its catchment on the eastern end while the remainder is rural. The topography of the lake indicates that the basin is natural, as northern and southern side of the lake is hilly while the western end has flat contours and forms the agricultural land. The location of Bhoj wetland along with the five sampling stations is depicted in Figure 1. Bhopal experiences a tropical climate with tropic of cancer passing through the state. It has hot summers and air temperature varies between 40 to $45^{\circ} \mathrm{C}$; winter is moderate. The maximum temperature recorded during the season is $45^{\circ} \mathrm{C}$. The year has been categorized into four seasons given as in Table 1.
The principal aim of this research paper is to evaluate how the temperature and other physico-chemical parameters affect the zooplankton diversity.

\section{Test protocol of physical and chemical parameters of water}

Different sites of the Wetland was visited monthly for a period of eight months (January to August 2009) to study the various ecological parameters such as water temperature, $\mathrm{pH}$, electrical conductivity, dissolved oxygen, free carbon dioxide, total alkalinity, total hardness, calcium, magnesium, chloride, and total dissolved solids. Surface water was collected from all the five sampling points (Figure 1). Collections were made using plastic containers of 21 capacity. The plastic containers were rinsed thoroughly with sampling water before using them. After filling the containers they were sealed and transferred to the laboratory for the estimation of various physical and chemical parameters by following standard methods (APHA, 1998). Water temperature at each sampling point was recorded on the spot using centigrade thermometer. The hydrogen ion concentration $(\mathrm{pH})$ was measured using $\mathrm{pH}$ meter (Systronics). Electrical conductivity was measured at $25^{\circ} \mathrm{C}$ in the calibrated conductivity bridge (Systronics-304). Calculation was made using cell constant 1.03. Water samples were taken carefully into $250 \mathrm{ml}$ reagent bottles avoiding air bubbles. The samples collected were fixed separately by using Winkler's method in the field itself for estimation of dissolved oxygen. Alkali-iodide azide and manganese sulphate reagents were added soon after the collection of water samples and the bottles were transported to the 
laboratory for further estimation. Later the D.O. was estimated in the laboratory dissolving the precipitate by adding concentrated sulphuric acid and then by titrating the samples against sodium thiosulphate $(0.025 \mathrm{~N})$ solution using starch as an indicator and the result has been expressed in $\mathrm{mg} / \mathrm{l}$. Carbon dioxide $\left(\mathrm{CO}_{2}\right)$ was estimated by titrating samples against $0.041 \mathrm{~N}$ Sodium hydroxide using phenolphthalein as an indicator. Total alkalinity of the samples were estimated by titrating against $0.02 \mathrm{~N}$ sulphuric acid using phenolphthalein and methyl orange as indicators and thus the bicarbonate alkalinities were calculated. Chloride was estimated by Argentometric method. Samples were titrated against silver nitrate and potassium chromate was used as an indicator. Total hardness of the water samples were determined by titrimetric method with EDTA $(0.01 \mathrm{~N})$ as titrant and Erichrome Black-T as an indicator. From the same method calcium and magnesium contents were also calculated and the results are expressed in $\mathrm{mg} / \mathrm{l}$. Total dissolved solids of the water samples were estimated by evaporation method and expressed in $\mathrm{mg} / \mathrm{l}$. All chemical analysis was completed on the day of sample collection.

\section{Zooplankton collection}

Water was collected from five sites of Bhoj wetland and filtered in a No. 25 bolting silk cloth net of mesh size $63 \mathrm{~mm}$ and $30 \mathrm{~cm}$ diameter. The final volume of the filtered sample was $100 \mathrm{ml}$. the sample was transferred to another $100 \mathrm{ml}$ plastic bottle and labelled mentioned the date and place of sampling. The samples collected in $100 \mathrm{ml}$ plastic bottles were preserved by adding 5 $\mathrm{ml}$ of $4 \%$ formaline.
The preserved samples were kept for 24 hours undisturbed to allow the sedimentation of plankton suspended in the water. After 24 hours, the supernatant was discarded carefully without disturbing the sediments and the final volume of the concentrated sample was $50 \mathrm{ml}$. the identification of zooplankton was done with the help of standard works viz., Edmondson (1959), Needham and Needham (1962), Adoni (1985). The species belonging to each group were noted down.

\section{Results and discussion}

The various physico-chemical parameters of Bhoj wetland is depicted in Table 2 and the monthly variations of the physico-chemical parameters is shown in Table 3. The list of Zooplankton species encountered during sampling in Bhoj wetland and their monthly variation is shown in Tables 4 and 5 respectively.

The current study was conducted for a period of eight months from January to August 2009 to investigate the zooplankton diversity in relation to physico-chemical characteristics of Bhoj wetland. The physico-chemical environment mainly controls the biological diversity. Due to the fluctuations in the physic-chemical characteristics, the biological diversity is affected. During the present investigation the average water temperature recorded during Jan, Feb, March, Apr, May, June, July, and Aug were 23, 24.5, 26.7, 25, 28, 30,33 and 31 respectively. The variation in water temperature may be due to different timing of collection and the influence of season (Jayaraman et al., 2003). Temperature controls behavioral characteristics of organisms, solubility of gases and salts in water. No other factor has 
so much influence as temperature (Welch, 1952). The rise in atmospheric temperature caused enhancement in the evaporation rate which resulted in colossal of water resulting in reduction in water depth. The positive correlation of Copepods with temperature indicated that the copepods develop better in warm periods after a mild and dump winter. This will result in a promotion of fish recruitment because the numbers of juvenile fish correlate very well with copepod biomass (Winkler, 2002). The better development of copepods during warmer and of rotifers during colder years coincides with the investigation of Heerkloss et al. (2005) on temperature dependent changes of the Darß-Zingst Lagoon plankton. It was shown that the annual mean biomass was significantly higher for copepods and lower for rotifers in warm years.

Transparency is a physical parameter in aquatic ecosystem and thus directly affects productivity. Even though the water body is shallow and overgrazed with microphytes but its transparency values were relatively high signifying the euphotic zone extends up till bottom at certain places. Wanganeo et al. (1997) also recorded high Secchi transparency in Bhoj wetland. Uniform distribution (more or less) of TDS have been found at all the five sites of the wetland.

The $\mathrm{pH}$ recorded during the present study was generally of near neutral to alkaline range suggesting that the lake water was well buffered throughout the period. During the investigation, rotifers were found mostly at sites $2(\mathrm{pH} 7.6)$ and $5(\mathrm{pH} 7.5)$ as compared to sites, 1 ( $\mathrm{pH} 7.4$ ), 3 ( $\mathrm{pH} 7.4$ ) and 4 ( $\mathrm{pH} 7.4)$. This indicates the positive correlation of $\mathrm{pH}$ - value and rotifers. While as Copepods were encountered frequently at sites 1, 3 and 4 as compared to sites 2 and
5 ; indicating a negative correlation of $\mathrm{pH}-$ value with copepods.

Relatively high values of DO have been recorded in the present study. At site 3 and 4 , slight reduction in DO which was in no way a matter of concern as even at their value flora and fauna could comfortably survive. The high Secchi values have been found to be responsible for enhancing the photosynthesis of autotrophs in deeper water. The increase in free $\mathrm{CO}_{2}$ at all the five sites of wetland indicates higher trophic status.

Chloride values in the present study were not alarming except at site 5, suggesting timely measures for stopping the entry of sewage and other run- off materials from its catchment area.

The rotifers (Brachnious Caudatus, Brachnious Quadridentata, Colurella spp, Gastropus spp, Harringia spp, Keratella cochlearis, Keratella tropica, Lecane spp, Monostyla spp, Notholca spp, Scardium $s p p$ ) was found dominanting the zooplanktonic pool at sites 2 and 5 . Copepoda (Calanoid copepod, Cyclopoid copepod, Cyclops spp, Diaptomus spp, Ectocyclops spp, Nauplis larvae) was found dominating the sites 1,3 and 4 . Site 2 was also dominated by Cladocera (Alona spp, Bosmina spp, Ceriodaphnia spp, Sida spp). Ostracoda (Cypris spp, Stenocypris spp) were found absent at Site 2 and 5. The dominance of rotifer (at sites 2 and 5) indicates the eutrophic nature of the water body. According to Brooks and Dodson (1965) selective predation by planktivorous fish results in the shifting of zooplankton communities with the dominance of rotifers. Sites 2 and 5 recorded high fish population and hence the dominance of rotifers.

The overall presence of Brachnious Caudatus and Keratella cochlearis confirms 


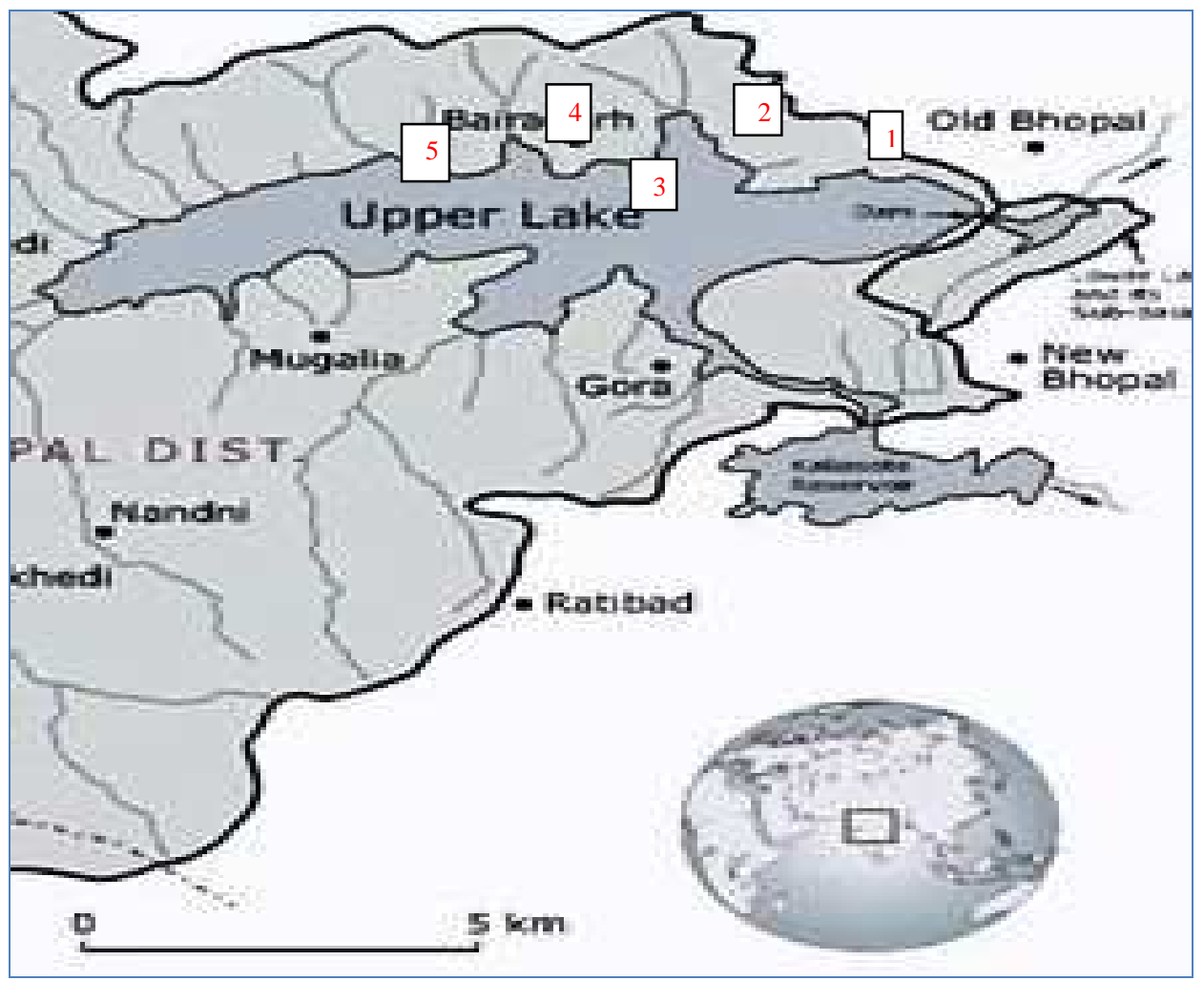

Figure 1. Location of study area along with the sampling stations

Table 1. Climate of the study area

\begin{tabular}{lll}
\hline Season & Months & Duration \\
\hline Winter & December- February & 3 \\
Summer & March- June & 4 \\
Monsoon & July- September & 3 \\
Post- monsoon & September- November & 2 \\
\hline
\end{tabular}

Table 2. Physico-chemical parameters of five sampling stations in Bhoj wetland, India (2009)

\begin{tabular}{lllllllllllll}
\hline Sites & T & ST & TDS & CD & pH & DO & FC & TH & CH & MH & TA & CL \\
\hline Site 1 & 28.5 & 1.2 & 112 & 172 & 7.4 & 9.3 & 13.5 & 76 & 73.5 & 6.6 & 105 & 22 \\
Site 2 & 27.6 & 1 & 125 & 174 & 7.6 & 9.3 & 14.5 & 75.4 & 75.4 & 5.4 & 97 & 25 \\
Site 3 & 28.4 & 1.3 & 110 & 171 & 7.4 & 9.5 & 13.2 & 75.3 & 70.1 & 4.7 & 88 & 18 \\
Site 4 & 27.7 & 1.2 & 111 & 171 & 7.4 & 9.3 & 13.4 & 75.4 & 72.4 & 5.3 & 95 & 19 \\
Site 5 & 27.5 & 1 & 113 & 173 & 7.5 & 9.4 & 14.3 & 75.9 & 75.8 & 4.8 & 100 & 24 \\
\hline
\end{tabular}

$\mathrm{T}=$ Temperature, $\mathrm{ST}=$ Secchi transparency, $\mathrm{TDS}=$ Total dissolve solid, $\mathrm{CD}=$ Conductivity, $\mathrm{DO}=$ Dissolve oxygen, $\mathrm{FC}=$ Free $\mathrm{Co}_{2}, \mathrm{TH}=$ Total hardness, $\mathrm{CH}=\mathrm{Ca}$ hardness, $\mathrm{MH}=\mathrm{Mg}$ hardness, $\mathrm{TA}=$ Total alkalinity, $\mathrm{CL}=$ Chloride. (All parameters except temperature, $\mathrm{pH}$ and Conductivity are measured in $\mathrm{mg} / \mathrm{l}$ ) 
I.A. Dar, H.A. Rather and M.A. Dar / Our Nature (2009) 7: 168-176

Table 3. Monthly variation in Physico-chemical parameters of water of Bhoj wetland, India (2009)

\begin{tabular}{lllllllll}
\hline P & Jan & Feb & March & April & May & June & July & August \\
\hline T & 23 & 24.5 & 26.7 & 25 & 28 & 30 & 33 & 31 \\
TDS & $90 \pm 2.5$ & $101 \pm 2.3$ & $95 \pm 1.4$ & $135 \pm 1.8$ & $130 \pm 1.6$ & $132 \pm 1.4$ & $111 \pm 2.1$ & $85 \pm 1.73$ \\
CD & $120 \pm 20.4$ & $135 \pm 18.2$ & $160 \pm 24.4$ & $180 \pm 17.1$ & $158 \pm 9.4$ & $129 \pm 7.8$ & $113 \pm 12.7$ & $102 \pm 0.09$ \\
pH & $7.5 \pm 0.3$ & $7.6 \pm 0.2$ & $7.7 \pm 0.3$ & $7.8 \pm 0.5$ & $7.6 \pm 0.7$ & $7.5 \pm 0.1$ & $7.4 \pm 0.2$ & $7.3 \pm 0.05$ \\
DO & $9.8 \pm 0.3$ & $9.6 \pm 0.8$ & $9.5 \pm 0.2$ & $9.7 \pm 0.4$ & $9.4 \pm 0.9$ & $9.3 \pm 0.3$ & $8.9 \pm 0.3$ & $9.1 \pm 0.42$ \\
FC & $13.7 \pm 0.4$ & $13.6 \pm 0.1$ & $13.5 \pm 0.9$ & $13.6 \pm 0.1$ & $13.4 \pm 0.5$ & $13.3 \pm 0.1$ & $13.2 \pm 0.9$ & $13.3 \pm 0.34$ \\
TH & $69.5 \pm 7.8$ & $70.1 \pm 1.4$ & $71.5 \pm 6.7$ & $70.2 \pm 8.7$ & $72.4 \pm 3.4$ & $74.4 \pm 2.6$ & $76.3 \pm 7.4$ & $75.8 \pm 6.3$ \\
CH & $68.9 \pm 6.7$ & $70.9 \pm 5.4$ & $72.7 \pm 5.9$ & $71.9 \pm 8.4$ & $72.8 \pm 4.8$ & $73.3 \pm 3.6$ & $75.1 \pm 5.9$ & $73.5 \pm 2.3$ \\
MH & $4.7 \pm 0.3$ & $4.9 \pm 0.9$ & $5.2 \pm 0.4$ & $5.1 \pm 0.2$ & $5.4 \pm 0.2$ & $5.9 \pm 0.7$ & $6.8 \pm 0.1$ & $6.1 \pm 0.09$ \\
TA & $92 \pm 2.7$ & $94 \pm 1.7$ & $99 \pm 3.1$ & $95 \pm 0.8$ & $100 \pm 0.9$ & $98 \pm 2.5$ & $107 \pm 1.6$ & $104 \pm 1.8$ \\
CL & $16 \pm 0.2$ & $18 \pm 0.5$ & $19 \pm 0.5$ & $17 \pm 0.4$ & $20 \pm 1.9$ & $23 \pm 1.3$ & $25 \pm 1.0$ & $19 \pm 1.76$ \\
& & & & & & & & \\
\hline
\end{tabular}

$\mathrm{P}=$ Parameters, $\mathrm{T}=$ Temperature, $\mathrm{TDS}=$ Total dissolve solid, $\mathrm{CD}=$ Conductivity, $\mathrm{DO}-$ Dissolve oxygen, $\mathrm{FC}=\mathrm{Free}$ $\mathrm{Co}_{2}, \mathrm{TH}=$ Total hardness, $\mathrm{CH}=\mathrm{Ca}$ hardness, $\mathrm{MH}=\mathrm{Mg}$ hardness, $\mathrm{TA}=$ Total alkalinity, $\mathrm{CL}=$ Chloride. (Values are mean \pm standard deviation and average of five sites. All parameters except temperature, $\mathrm{pH}$ and Conductivity are measured in $\mathrm{mg} / \mathrm{l})$

Table 4. List of Zooplankton species encountered during sampling in Bhoj wetland, India (2009)

\begin{tabular}{|c|c|c|c|c|c|c|}
\hline Class & Species & Site 1 & Site 2 & Site 3 & Site 4 & Site 5 \\
\hline Rotifera & $\begin{array}{l}\text { Brachnious caudatus } \\
\text { Brachniousquadridentata } \\
\text { Colurella spp } \\
\text { Gastropus spp } \\
\text { Harringia spp } \\
\text { Keratella cochlearis } \\
\text { Keratella tropica } \\
\text { Lecane spp } \\
\text { Monostyla spp } \\
\text { Notholca spp } \\
\text { Scardium spp }\end{array}$ & $\begin{array}{l}- \\
- \\
+ \\
- \\
+ \\
- \\
- \\
+ \\
- \\
+ \\
-\end{array}$ & $\begin{array}{l}+ \\
+ \\
+ \\
+ \\
+ \\
+ \\
+ \\
+ \\
+ \\
+ \\
+\end{array}$ & $\begin{array}{l}+ \\
- \\
- \\
- \\
+ \\
- \\
+ \\
- \\
- \\
+ \\
+\end{array}$ & $\begin{array}{l}+ \\
- \\
- \\
- \\
+ \\
- \\
- \\
+ \\
- \\
- \\
-\end{array}$ & $\begin{array}{l}+ \\
+ \\
+ \\
+ \\
+ \\
+ \\
- \\
+ \\
+ \\
+ \\
+\end{array}$ \\
\hline Copepoda & $\begin{array}{l}\text { Calanoid copepod } \\
\text { Cyclopoid copepod } \\
\text { Cyclops spp } \\
\text { Diaptomus spp } \\
\text { Ectocyclops spp } \\
\text { Nauplis larvae }\end{array}$ & $\begin{array}{l}+ \\
+ \\
+ \\
- \\
+ \\
+\end{array}$ & $\begin{array}{l}+ \\
- \\
+ \\
- \\
+ \\
-\end{array}$ & $\begin{array}{l}+ \\
+ \\
+ \\
+ \\
+ \\
-\end{array}$ & $\begin{array}{l}+ \\
+ \\
+ \\
+ \\
+ \\
+\end{array}$ & $\begin{array}{l}- \\
- \\
+ \\
+ \\
+ \\
+\end{array}$ \\
\hline Cladocera & $\begin{array}{l}\text { Alona spp } \\
\text { Bosmina spp } \\
\text { Ceriodaphnia spp } \\
\text { Sida spp }\end{array}$ & $\begin{array}{l}+ \\
+ \\
+\end{array}$ & $\begin{array}{l}- \\
- \\
+ \\
+\end{array}$ & $\begin{array}{l}- \\
- \\
- \\
+\end{array}$ & $\begin{array}{l}- \\
+ \\
-\end{array}$ & $\begin{array}{l}- \\
+ \\
- \\
+\end{array}$ \\
\hline
\end{tabular}


I.A. Dar, H.A. Rather and M.A. Dar / Our Nature (2009) 7: 168-176

\begin{tabular}{lllllll}
\hline Protozoa & Amoeba spp & - & - & + & + & + \\
& Difflugia spp & - & + & - & + & - \\
& Euglypha spp & - & + & + & - & + \\
& Glaucoma spp & - & - & + & + & + \\
& Trinema spp & - & + & - & + & - \\
\hline Ostracoda & Cypris spp & + & - & + & + & + \\
& Stenocypris spp & + & - & - & + & - \\
\hline
\end{tabular}

Table 5. Monthly variation in Zooplankton species in Bhoj wetland, India (2009)

\begin{tabular}{|c|c|c|c|c|c|c|c|c|c|}
\hline Class & Species & Jan & Feb & March & April & May & June & July & Aug \\
\hline \multicolumn{10}{|l|}{ Rotifera } \\
\hline & Brachnious Caudatus & + & + & + & + & + & - & - & - \\
\hline & Brachnious quadridentata & + & + & - & - & + & - & - & - \\
\hline & Colurella spp & + & + & + & - & - & - & - & - \\
\hline & Gastropus spp & + & + & - & + & - & - & - & - \\
\hline & Harringia spp & + & + & + & + & - & - & - & - \\
\hline & Keratella cochlearis & + & + & - & - & + & - & - & - \\
\hline & Keratella tropica & + & + & + & + & - & - & - & - \\
\hline & Lecane spp & + & + & + & + & - & - & - & - \\
\hline & Monostyla spp & + & + & - & - & + & - & - & - \\
\hline & Notholca spp & + & + & + & - & + & - & - & - \\
\hline & Scardium spp & + & + & + & - & + & - & - & - \\
\hline \multicolumn{10}{|l|}{ Copepoda } \\
\hline & Calanoid copepod & - & - & - & + & + & + & + & + \\
\hline & Cyclopoid copepod & - & - & - & + & + & + & + & + \\
\hline & Cyclops spp & - & - & - & + & + & + & + & + \\
\hline & Diaptomus spp & - & - & - & + & + & + & + & + \\
\hline & Ectocyclops spp & - & - & - & + & + & + & + & + \\
\hline & Nauplis larvae & - & - & - & + & + & + & + & + \\
\hline \multirow[t]{4}{*}{ Cladocera } & Alona spp & + & + & + & - & - & - & - & - \\
\hline & Bosmina spp & + & + & - & + & + & - & + & + \\
\hline & Ceriodaphnia spp & + & + & - & - & - & + & & - \\
\hline & Sida spp & & + & + & - & + & - & - & - \\
\hline \multirow[t]{5}{*}{ Protozoa } & Amoeba spp & - & + & + & + & + & + & + & + \\
\hline & Difflugia spp & - & + & - & + & - & - & + & - \\
\hline & Euglypha spp & - & + & + & - & + & + & - & + \\
\hline & Glaucoma spp & - & + & + & + & + & - & - & + \\
\hline & Trinema spp & + & + & - & + & - & + & - & - \\
\hline \multirow[t]{2}{*}{ Ostracoda } & Cypris spp & + & - & + & + & + & + & + & - \\
\hline & Stenocypris spp & + & - & - & + & - & + & + & - \\
\hline
\end{tabular}


that the lake water is slightly enriched. Such results were also reported by Kundannagar and zutshi (1985).The abundance of Cladocerans and least contribution of Protozoa (Site 1) in the community structure indicate less organic load in the system. Similar results have been observed by Rao et al. (1988).

\section{Conclusion}

1. The Physico-chemical environment mainly controls the biological diversity.

2. The positive correlation of Copepods with temperature indicated that the copepods develop better in warm periods. Based on the assessment and observations during various research surveys, I have evaluated the relationship between the growth and density of Copepod zooplankton with its immediate environs as shown below.

$\mathrm{W}_{\text {cop }}=\mathrm{K}$. (T) $\div \mathrm{pH}$. $\lambda$. X

to Imran Ahmad Dar)

Where, $\mathrm{W}_{\text {Cop }}$ denotes the growth of the Copepods; $\mathrm{T}$ defines the temperature; $\mathrm{pH}$, indicates the power of hydrogen ion concentration; $\lambda$ denotes the latitude; $\mathrm{X}$ denotes the grazing pressure of the planktanivorous fishes and $\mathrm{K}$ is the proportionality constant (depends on environmental conditions like ppt., humidity, geology of the basin, soil type, terrain etc.)

This formula clearly depicts that the density and growth of Copepods will be more during warming periods but its growth is almost hampared with the high values of $\mathrm{pH}$ and decreases with the increase in latitude (growth decreases towards the equator) and also decreases with the increasing grazing pressure planktivorous fishes.
3. The positive correlation of rotifers and $\mathrm{pH}$ - value indicated that they mainly prefer the alkaline medium for their growth. For rotifers, the following formula has been evaluated.

$\mathrm{W}_{\text {Roti. }}=\mathrm{K} .(\mathrm{pH}) \div \mathrm{X} \quad$------- (C) to

Imran Ahmad Dar)

Where, $\mathrm{W}_{\text {Roti }}$ denotes the growth of the Rotifers; ; $\mathrm{pH}$, indicates the power of hydrogen ion concentration; $\mathrm{X}$ denotes the grazing pressure of the planktivorous fishes and $\mathrm{K}$ is the proportionality constant (depends on environmental conditions like ppt., humidity, geology of the basin, soil type, terrain etc.).

From the above relationship, we can see that growth of Rotifers is mainly affected by the grazing pressure of the planktanivorous fishes. Rest of the work should be done by other researchers.

4. The negative correlation of $\mathrm{pH}$ - value with copepods clearly showed their dominance in a medium of low $\mathrm{pH}$.

5. The increase in free $\mathrm{CO}_{2}$ at all the five sites of the wetland indicated higher trophic status.

6. The overall presence of Brachnious Caudatus and Keratella cochlearis confirmed that the lake water is slightly enriched.

\section{References}

Adoni, A.D. 1985. Work book of limnology. Pritibha Publication, Sagar, M.P., India.

APHA 1998. Standard methods for the examination of water and waste water $\left(19^{\text {th }}\right.$ Ed.). New York: American Public Health Association. Inc.

Brooks, J.L. and S.J. Dodson 1965. Predation, body size and composition of plankton. Sci. 150: 28-35.

Edmondson, W.T. 1959. Ward and Whiple's freshwater biology ( $2^{\text {nd }} \mathrm{Ed}$.). John Wiley and sons Inc., New York, 1248p. 
I.A. Dar, H.A. Rather and M.A. Dar / Our Nature (2009) 7: 168-176

Gupta, M.C. and L.L. Sharma 2007. Trophic status and zooplankton of Amarchand reserviour, Udaipur, Rajastan. C.P. 02: NSL 2007.

Heerkloss, R., T. Rieling and H. Schubert 2005. Long-term studies of temperature dependent plankton community changes in an estuarine system of the southern Baltic sea. icam dossiers nr. 3: Lagoons and coastal wetlands in the global change context: impact and management issues. Proceedings of the International Conference, Venice, 26-28 April, 2004. pp. 159-164.

Jayaraman, P.R., T. Ganga Devi and T. Vasudena Nayar 2003. Water quality studies on Karamana river, Thiruvananthapuram District South Kerela, India. Poll. Res. 22(1): 89-100.

Kundannagar, M.R. and D.P. zutshi 1985 Environmental features and plankton communities of two Himalayan rural lakes. In Proc. Nat. Symp. Pure and Applied Limnology (Ed. A.D. Adoni), Bull. Bot. Soc., Sagar 32: 40-47.

Needham, J.G. and P.R. Needham 1962. A guide to study the freshwater biology. Holden-Dey Inc., Francisco. 108p.
Rao, N.G., V.S. Durve and V.J. Shrikhande 1988. Acta. Hydrochim. Hydrobiol. 16: 517-524.

Sharma, M.S., V. Sharma and H. Malara 2007. Biodiversity of zooplankton in relation to different types of aquatic pollution. C.P. 46. NSL 2007. pp. 300-302.

Wanganeo, A. 2007. Plankton; its uses for the benefit of mankind and its utility in water management. I.T. 09. pp. 43-50.

Wanganeo, A., R. Wanganeo and S. Pani 1997. Summer dissolved oxygen regimes in tropical Vindhyan lake in relation to its conservation strategy. Strategy Bionature 17(1): 7-11.

Waters, T.F. 1987. Adv. Ecol. Res. 10: 11-164.

Welch, P.S. 1952. Limnological methods. New York: McGraw-Hill.

Winkler, H.M. 2002. Effects of eutrophication on fish stocks in Baltic lagoons. In Baltic Coastal Ecosystems (Eds. G. Schernewski and U. Schiewer), Springer-Verlag, Berlin. pp. 65-74. 